University of Nebraska - Lincoln

DigitalCommons@University of Nebraska - Lincoln

Faculty Publications from the Harold W. Manter Laboratory of Parasitology

10-1996

\title{
Hemorrhagic Gastritis in Free-Living Rodents in Idaho
}

\author{
Patricia G. Wilber \\ University of New Mexico \\ Donald W. Duszynski \\ University of New Mexico, eimeria@unm.edu \\ B. Van Horne \\ Colorado State University
}

Follow this and additional works at: https://digitalcommons.unl.edu/parasitologyfacpubs

Part of the Parasitology Commons

Wilber, Patricia G.; Duszynski, Donald W.; and Van Horne, B., "Hemorrhagic Gastritis in Free-Living Rodents in Idaho" (1996). Faculty Publications from the Harold W. Manter Laboratory of Parasitology. 193. https://digitalcommons.unl.edu/parasitologyfacpubs/193

This Article is brought to you for free and open access by the Parasitology, Harold W. Manter Laboratory of at DigitalCommons@University of Nebraska - Lincoln. It has been accepted for inclusion in Faculty Publications from the Harold W. Manter Laboratory of Parasitology by an authorized administrator of DigitalCommons@University of Nebraska - Lincoln. 


\section{Hemorrhagic Gastritis in Free-Living Rodents in Idaho}

Patricia G. Wilber,' Donald W. Duszynski,' and Beatrice Van Horne,2 'The University of New Mexico, Department of Biology, Albuquerque, New Mexico 87131, USA, ${ }^{2}$ Colorado State University, Department of Biology, Ft. Collins, Colorado 80253, USA

ABSTRACT: Between February 1992 and March 1994, four species of rodent from the Snake River Birds of Prey Area near Boise, Idaho (USA) were necropsied. Hemorrhagic gastritis was observed in 16 of 131 Townsend's ground squirrels (Spermophilus townsendii), one of 11 Ord's kangaroo rats (Dipodomys or$\mathrm{dii}$ ) and the one Great Basin pocket mouse (Perognathus parous) evaluated. No lesions were observed in 14 white-footed deer mice (Peromyscus maniculatus). Tissue from one Townsend's ground squirrel was negative for Helicobacter sp.-like bacteria.

Key words: Hemorrhagic gastritis, Gastric lesions, Spermophilus, Dipodomys, Peromyscus, Perognathus, rodent, Idaho.

Gastrointestinal ulceration is a concern for human health, domestic animal production and zoo management. Skinner (1922) reported that wild pronghorns (Antilocapra americana) did not adjust well to captivity and often developed stress-related stomach ulcers. Selye (1936) first showed that stomach ulcers could be experimentally induced in rats exposed to stressors such as cold and excessive exercise. Gastric lesions, including hemorrhage and ulceration, resulting from Selye's Syndrome (stress) have subsequently been reported from captive and domestic mammals including zebras (Equus sp.), rhinoceroses (Diceros sp.), ranch-raised mink (Mustela vison) (Wallach and Boever, 1983), pigs (Sus scrofa) (Hessing et al., 1992) and vervet monkeys (Cercopithecus aethiops) (Suleman et al., 1995). Gastric lesions also have been correlated with the bacterium Helicobacter pylori in humans (Graham, 1991) and H. pylori and Gastrospirillum spp.-like organisms in captive cheetahs (Acinonyx jubatus) (Eaton et al., 1993), nematode infection in domestic cats (Felis domesticus) (Curtsinger et al., 1993), canine distemper in captive black-footed ferrets (Mustela nigripes) (Williams et al.,
1988), and creosote poisoning in black rhinoceroses (Diceros bicornis) (Kock et al., 1994). Reports of gastric lesions from freeliving animals appear to be rare; however, gastric erosion and hemorrhage has been observed in 83 (55\%) of 152 oil contaminated and four $(6.5 \%)$ of 62 non-contaminated carcasses of sea otters (Enhydra lutris) that died in the wild at Prince William Sound, Alaska (USA) (Lipscomb et al., 1994).

Between February 1992 and March 1994 we surveyed four species of rodent at the Snake River Birds of Prey Area (SRBOPA) $\left(43^{\circ} 17^{\prime} \mathrm{N}, 116^{\circ} 25^{\prime} \mathrm{W}\right)$, Idaho (USA), for intestinal helminths. In the course of this study, we observed hemorrhagic gastritis in Townsend's ground squirrels (Spermophilus townsendii), Ord's kangaroo rats (Dipodomys ordii) and one plains pocket mouse (Perognathus parvus). To our knowledge, this is the first report of gastric lesions in these rodents.

During our study, we examined 131 Townsend's ground squirrels, 11 Ord's kangaroo rats, one Great Basin pocket mouse, and 14 white-footed deer mice, (Peromyscus maniculatus) from the SRBOPA. Townsend's ground squirrels are obligate hibernators (Rickart, 1982) and are active only from February to June in most years (Smith and Johnson, 1985). During monthly collections in 1992, we collected a total of 76 adult squirrels. Juveniles emerged from their natal burrows in March and April in 1992 and we collected 46 juveniles between April and June. Squirrels were collected in single-door, wire-mesh collapsible live-traps (Tomahawk No. 201, Tomahawk, Wisconsin, USA) during the day, transported to the lab by 5:00 p.m. and immediately euthanized with Halothane (Sigma, St. Louis, 


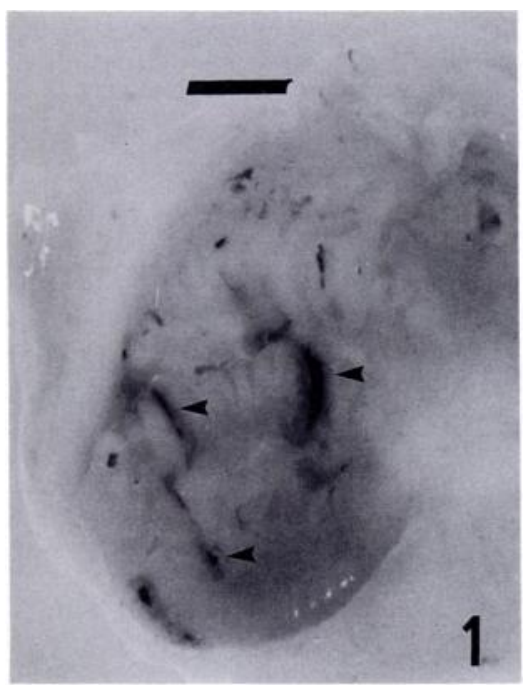

FIGURE 1. Macroscopic view of hemorrhagic lesions (arrow heads) in the stomach of a female Townsend's ground squirrel (Spermophilus tounsendii) from the Snake River Birds of Prey Area, Idaho. Scale bar $=5 \mathrm{~mm}$.

Missouri, USA). Carcasses were frozen at $-20 \mathrm{C}$ until necropsy in June 1992. In 1993, four trap mortalities from a markrecapture study and five animals that were found dead were necropsied in August 1993. The prevalence of stomach lesions in adult versus juvenile squirrels was compared using Fisher's Exact Test (Mehta and Patel, 1992). Relative body condition (excellent, good, fair, poor) in squirrels was estimated from the relative abundance of fat in the abdominal cavity. Body masses of squirrels with lesions versus squirrels without lesions was compared using a two sided $t$-test (Zar, 1984) for animals for which we had those data. Two squirrels that died after being held in captivity for less than a month also had lesions. These animals were not included in the totals or the statistical analyses, but a macroscopic view of a fresh stomach with lesions (Fig. 1) and a photomicrograph of a lesion (Fig. 2) were obtained from the adult female squirrel, captured on 9 February 1993 and which died in captivity on 25 February 1993. This animal was necropsied shortly after death and lesions were photographed

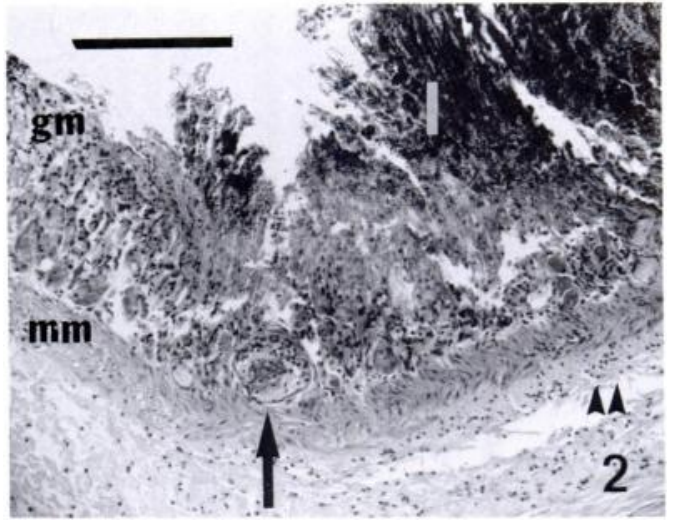

Figure 2. Histological section of a portion of a stomach lesion in a female Townsend's ground squirrel (Spermophilus townsendii) from the Snake River Birds of Prey Area, Idaho USA. Note normal gastric mucosa ( $\mathrm{gm}$ ) on the left and lesion (1) on the right; the lesion does not extend through the muscularis mucosae $(\mathrm{mm})$; the sparse mixed inflammatory cell infiltration (arrowheads) in the submucosa; and the accumulation of fibrin thrombi in the small vessels at the base of the lesion (arrow). Hematoxylin and losin. Scale bar $=0.2 \mathrm{~mm}$.

immediately. The tissue was fixed for $24 \mathrm{hr}$ in aqueous Bouin's fixative (Pritchard and Kruse, 1982), rinsed for $12 \mathrm{hr}$ in tap water, and embedded in paraffin. Specimens were sectioned ( 3 to $4 \mu \mathrm{m}$ ) and stained in Harris' hematoxylin and eosin. Samples from this one stomach were examined for Helicobacter sp.-like organisms using Warthin-Starry silver stain (Luna, 1992).

The other three species of rodent are active all year, but we collected specimens only on 15 and 16 March 1994. Animals were euthanized on site with Halothane and transported to the lab within $1 \mathrm{hr}$ where they were frozen $(-20 \mathrm{C})$ until necropsy in April 1994 or April 1995. No weights or body condition estimates were obtained for these individuals. Stomach tissue from two animals with stomach lesions also was fixed and sectioned, except that this tissue had been frozen prior to preservation and sectioning. These tissues were not tested for Helicobacter sp.-like organisms.

Gastric abnormalities were first observed macroscopically during the necrop- 


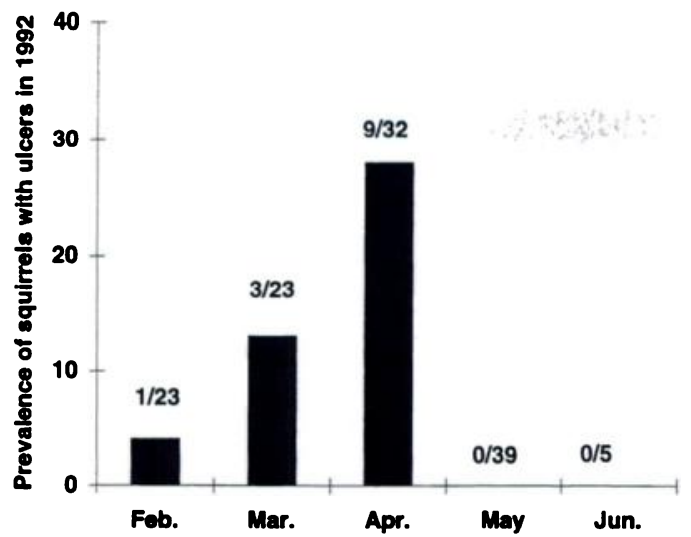

Ficure 3. The prevalence (number positive/number sampled) of stomach lesions in a freeliving population of Townsend's ground squirrels at the Snake River Birds of Prey Area, Idaho by month in 1992.

sy examination of Townsend's ground squirrels. Although we prepared histological sections from only one fresh squirrel stomach and one frozen stomach each from a kangaroo rat and a pocket mouse, the macroscopic abnormalities were unmistakable. They included slits that ranged from 1 to $2 \mathrm{~mm}$, to about $10 \mathrm{~mm}$ in length (Fig. 1), were consistently dark-red to black, were hemorrhagic in appearance and could not be removed by scraping the surface. These lesions were observed in 13 (11\%) of 122 squirrels in 1992 and three of nine squirrels in 1993. In 1994, no squirrels were sampled, but one of 11 kangaroo rats and one of one pocket mouse had lesions. None of the 14 deer mice examined in 1994 had lesions.

In 1992, the prevalence of these lesions in the squirrel population that was sam- pled increased from February to April, but declined to zero in May and June (Fig. 3). Lesions were more likely $(P<0.05)$ to occur in juveniles (eight of $46,17 \%$ ) than in adults (five of $76,7 \%$ ). All juveniles with lesions were in poor condition with little or no abdominal fat while adults with lesions (only females) had body conditions that ranged from poor to good. Juveniles with lesions had a significantly lower $(P<$ $0.01)$ mean body mass than those with no lesions (Table 1). The mean body mass of adult females with lesions was less than for adult females without lesions, but the difference was not significant (Table 1).

In 1993, three of nine squirrels had the lesions. Interestingly, lesions occurred in three of five squirrels found dead on trap sites but in none of four squirrels that died due to trap-stress. There was no difference in prevalence of lesions between adults (one of three) and juveniles (two of six). Animals with lesions always lacked abdominal body fat. The mean body mass for squirrels with lesions was less than for squirrels without lesions, but the difference was not significant (Table 1). All three squirrels with lesions were male.

Based on the microscopic examination of the lesions in the female ground squirrel that died in captivity (Fig. 2), necrosis and hemorrhage involved half to threefourths of the thickness of the mucosa. Fibrin thrombi were evident in the small vessels at the base of the lesions and there was accumulation of proteinaceous fluid and a sparse, mixed inflammatory cell infiltrate in the submucosa. The lesions did

TABLE 1. Mean \pm SD body mass $(\mathrm{g})$ of adult and juvenile Townsend's ground squirrels (Spermuphilus tounsendii) with and without stomach lesions at the Snake River Birds of Prey Area, Idaho, in 1992 and 1993. Sexes were combined when both males and females were captured.

\begin{tabular}{llcrrr}
\hline Year & \multicolumn{1}{c}{ Age } & $\begin{array}{l}\text { Number } \\
\text { sampled }\end{array}$ & $\begin{array}{c}\text { Lesions } \\
\text { present }\end{array}$ & $\begin{array}{c}\text { Number } \\
\text { sampled }\end{array}$ & $\begin{array}{c}\text { Lesions } \\
\text { absent }\end{array}$ \\
\hline 1992 & Juveniles & 7 & $69 \pm 15^{\mathrm{a}}$ & 33 & $103 \pm 29$ \\
1992 & Adult females & 4 & $158 \pm 42$ & 36 & $163 \pm .39$ \\
1993 & Juveniles & 2 & $46 \pm 25$ & 4 & $75 \pm .32$ \\
1993 & Adult males & 1 & 128 & 1 & 226 \\
\hline
\end{tabular}

a Significantly $(P<0.01)$ lower than animals without lesions. 
not extend through the muscularis mucosa. The prepared sample was examined for Helicobacter spp.-like organisms after staining with Warthin-Starry silver stain, but no silver-positive organisms were detected.

Microscopically, the lesions in the kangaroo rat and the pocket mouse were similar to those in the ground squirrel. However, there was no inflammation in the lamina propria.

In summary, this is the first report of hemorrhagic gastritis in Townsend's ground squirrel, Ord's kangaroo rat, and plains pocket mouse. Additional testing is needed to determine the possible causative agents. Of the 16 squirrels with lesions, 11 had poor body condition, two were in fair condition and one was in good condition. No squirrels in excellent condition were affected. Prevalence of ulceration increased in the squirrel population we sampled from February to April (Fig. 3). During this time (February to June) there was a severe drought at the SRBOPA that negatively impacted both individual squirrels and the squirrel population (Wilber et al., 1996). This relation between poor body condition and increased prevalence of stomach lesions supports the hypothesis that higher incidence of disease may occur when animals are in poor physical condition (Esch et al., 1975; Scott, 1988). The absence of lesions in May and June of 1992 is puzzling, but perhaps affected animals were in such poor physical condition that they had died or had begun dormancy by May.

We suspect that similar lesions, including true gastric ulceration, may occur in wild rodents in a variety of locations, but among hundreds of rodents ( $>20$ species) necropsied in North and South America, such lesions have never been observed (D. Duszynski, unpubl.). Further study on hemorrhagic gastritis and possible ulceration in wild rodents is warranted.

We thank D. Leatherwood and all of the technicians who collected ground squirrels at the SRBOPA in 1992 and 1993, J.A.
Hnida and Dr. M. J. Patrick for helpful comments on earlier drafts of this manuscript, the New Mexico Department of Agriculture Veterinary Diagnostic Services for tissue section preparation and interpretation, especially M. Behr, DVM, and the Texas Veterinary Medical Diagnostic Laboratory, Amarillo for the silver staining. This work was funded by Bureau of Land Management (BLM) contract as a component of the BLM/Idaho Army National Guard integrated study of raptor-prey relationships in the SRBOPA (contract YA651-CTO-340032) to B.V.H. and grants from the Graduate Research Allocation committee, the Student Research Allocations Committee, the Vice President's Graduate Research Fund, and the Graduate Research and Travel Fund at the University of New Mexico to P.G.W.

\section{LITERATURE CITED}

Curtsinger, D. K., J. L. Carpenter, and J. L. TurNER. 1993. Gastritis caused by Aonchotheca putorii in a domestic cat. Journal of the American Veterinary Medical Association 203:1153-1154.

Eaton, K. A., M. J. Radin, L. Kramer, R. Wack, R. Sherding, S. Krakowka, J. G. Fox, and D. R. MORGAN. 1993. Epizootic gastritis associated with gastric spiral bacilli in cheetahs (Acinonyx jubatus). Veterinary Pathology 30:55-63.

Esch, G. W., J. W. Gibbons, and J. E. Bourque. 1975. An analysis of the relationship between stress and parasitism. American Midland Naturalist 93:339-353.

Graham, D. Y. 1991. I. Helicobacter pylori: Its epidemiology and its role in duodenal ulcer disease. Journal of Gastroenterology and Hepatology 6: 105.

Hessing, M. J. C., M. J. Geudeke, C. J. M. ScheePENS, M. J. M. TiElen, W. G. P. SCHOUTEN, AND P. R. WiEPKema. 1992. Mucosal lesions in the pars oesphagea in pigs: Prevalence and influence of stress. Tijdschrift voor Diergeneeskunde 117: $445-450$

Kock, N. D., M. D. Kock, AND K. B. Young. 1994. Hepatopathy in 2 black rhinoceroses (Diceros bicornis) in Zimbabwe: Creosote toxicosis. Journal of Zoo and Wildlife Medicine 25:270-273.

Lipscomb, T. P., R. K. HaRris, A. H. Rebar, B. E. Ballachey, and R. J. HaEbler. 1994. Pathology of sea otters. In Marine mammals and the Exxon Valdez, T. R. Loughlin (ed.). Academic Press, Inc. San Diego, California, pp. 265-280.

LUNA, L. G. 1992. Histopathologic methods and col- 
or atlas of special stains and tissue artifacts American Histolabs, Inc. Gaithersburg, Maryland, p. 217.

Mehta, C., ANd N. Patel. 1992. StatExact. Cytel Software, Corporation, Cambridge, Massachusetts, pp. 5.1-5.70:

Pritchard, M. H., AND G. O. W. Kruse. 1982. The collection and preservation of animal parasites. University of Nebraska Press, Lincoln, Nebraska, p. 120.

RICKART, E. A. 1982. Annual cycles of activity and body composition in Spermophilus townsendii mollis. Canadian Journal of Zoology 60:32983306.

ScOTT, M. E. 1988. Impact of infection and disease on animal populations: Implications for conservation biology. Conservation Biology 2:40-56.

SElye, H. 1936. A syndrome produced by diverse nocuous agents. Nature 138:32.

SKINNER, M. P. 1922. The pronghorn. Journal of Mammalogy 3:82-105.

SMITH, G. W., AND D. R. Johnson. 1985. Demography of a Townsend ground squirrel population in southwestern Idaho. Ecology 66:171-178.
Suleman, M. A., R. P. Tarara, J. G. Else, and P. D. SAYER. 1995. Spontaneous acute gastric-mucosal erosions and ulcerations in vervet monkeys (Cercopithecus aethiops). Journal of Zoo and Wildlife Medicine 26:67-71.

Wallach, J. D., AND W. J. Boever. 1983. Diseases of exotic animals: Medical and surgical management. W.B. Saunders Company, Philadelphia, Pennsylvania, pp. 522 and 808.

Wilber, P. G., M. J. Patrick, and B. Van Horne. 1996. Helminth infections in the Townsend's ground squirrel during drought. Journal of the Helminthological Society of Washington 63: 233-239.

Williams, E. S., E. T. Thorne, M. J. G. APPEL, AND D. W. BELITSKY. 1988. Canine distemper in black-footed ferrets (Mustela nigripes) from Wyoming. Journal of Wildlife Diseases 24:385-398.

ZAR, J. H. 1984. Biostatistical Analysis, 2nd edition. Prentice-Hall, Englewood Cliffs, New Jersey, $718 \mathrm{pp}$.

Received for publication 4 December 1995. 